\title{
In the Name of Public Interest We Evict? (Re-actualizing the Standing Position of Proletarian Jurisprudence to the Marginalized)
}

\author{
Iffatin Nur
}

State Islamic Institute (IAIN) of Tulungagung - East Java, Indonesia

DOI: $10.36348 / \mathrm{sjhss} .2020 . v 05 i 02.001$

| Received: 05.02.2020 | Accepted: 13.02.2020 | Published: 18.02.2020

*Corresponding author: Dr. Iffatin Nur

Email: iffaeltinury@gmail.com

\section{Abstract}

The phenomena of evictions of street vendors, homeless people, poor peasants, illegal settlers, etc. have been common in Indonesia. The weak proletariats are always sacrificed whenever they are vis a vis the bourgeois groups and rulers. If done continuously, the preservation of their religion, souls, intelligences, offspring, properties, and dignities will be menaced. So, re-actualizing fiqh mustad'afin (the proletarian jurisprudence) is urgently necessitated. This research calls for a re-conceptualisation of fiqh mustad'afin to present its importance and role in defending the rights of those oppressed group. The research was a mix-method type. Apart from studying related literature, it also employed fieldwork by interviewing a number of street vendors and government officers in Malang City, East Java, Indonesia. The results show that fiqh mustad'afin does belong to and favor those who are weak and oppressed and places those who do wrong and unjust as common enemies that must be fought.

Keywords: Fiqh mustaḍ'afìn; maqāṣsid sharī'ah; marginal; proletarian jurisprudence; reactualization.

Copyright @ 2020: This is an open-access article distributed under the terms of the Creative Commons Attribution license which permits unrestricted use, distribution, and reproduction in any medium for non-commercial use (NonCommercial, or CC-BY-NC) provided the original author and source are credited.

\section{INTRODUCTION}

Islam as a religion of universal prosperity, devotes its benefit to all people regardless of any physical barrier and boundary. Fiqh (Islamic jurisprudence), as one meansfor actualizing the Islamic teachings' isoteric and esoteric values, has a concept which inclines to minority and marginalized groups which is eventually known as fiqh mustad'afin. This conception of fiqhstands in solidarity and fights for the rights of the marginalized and the lowest layer of society who are often persecuted and oppressed [1].

This disruptionera necessitatesa movement to re-establish the universal Islamic beneficial values through re-actualizing fiqh mustad'afin. This is sparked by occurring phenomena of some massive evictions of minorities' business places, homeless people, poor peasants, illegal settlers, as well asimproper conversion of irrigational, educational, green and other public spaces, and agricultural fields in many Indonesian regions into industrial and business spacesthrough power abuses of someirresponsible policy makers collaborating with the mere profit-oriented capital owners.
During the reign of the New Order political regime, the takeover of land cultivated by Indonesian peasants and transforming them as new asset of capital owners did not only involve local financial institutions but also international financial institutions such as the World Bank, IMF, etc. At least, the index of human rights violation released by the Indonesian Centre for Legal Studies and Community's Advocation on October 1997 recorded that there were 891 cases of human rights violations in the form of land takeover through various means carried out by the New Order regime. Ironically, these violations only took 27 months, from July 1994 to September 1996 [2]. The New Order regime had truly facilitated the power of capital to express itself on a large scale. The capitalism economic system eventuallyturned out oppressing the weak, especially migrant workers, who come to the cities through the economic informal sectors, one of them is being street vendors. In Indonesia, they are called Pedagang Kaki Lima, abbreviated as PKL.

Legally, according to some Indonesian regulations, street vendors, hereinafter referred to PKLs, are business actors conducting trading businesses utilizing mobile or immobile business means andoccupying temporarily/non-permanently municipal 
infrastructure, social or public facilities, landand buildings belonging to the Government and/or private entities [3]. PKL, which literally means "a five feet trader", was a term taken from the Dutch regulations during their colonial era regarding the width of sidewalk in front of the shops which must be at least 5 feet wide. This regulation was made to ensure the safety and comfort of pedestrians. Any trader conducting their activities on that sidewalk was known as five feet traders(Pedagang Kaki Lima, abbreviated as PKLs, Ind.). Hence, the term PKL were pinned onto them [4]. We use the terms PKL and street vendor interchangably throughout this paper.

PKL growsowing to its simplicity with no convoluted bureaucratic procedure; it requires relatively smallamount of money to start with, and does not necessitate a high educational background, in other words, anyone with determination and small capital can do it. Becoming a PKLis a logical option for migrants since such profession is regarded able to provide jobs for them in the midst of intense urban economic competition and less availability of proper employment. The fast progress of informal sectors, including PKL, in the city is inseparable from the acceleration of its population growth and the imbalance of work-force number with the available jobs [5]. Urbanization for seeking employment is one of the causes of the growing development of informal sectors in the city. In addition, Malang City is a shopping city, so it is just natural that the unemployed take positive compensation by opting to work in entrepreneurial sectors; one of informal sectorsthey chooseis beinga PKL.

The policy of evicting PKLs in the name of preserving the city's beauty and order is considered paradox when urban area becomes an economic battlefield for the political and capital-owner elites. In such a situation, those PKLs, especially migrants, fight their fate in the city. They can do nothing but scavenge spices scattered from capitalism practices through their marginal (indecent) jobseven though they have to be vis $a$ vis with many city's regulations quibbling on the city's agenda which are mostly in the context of city's cleanliness, beauty, and comfort. No way in, nowayout is just the right adage to describe the position of street vendors in an effort to fulfill their family needs for life. Some policies and regulations have been compiled and issued to regulate and organize PKLs, but, frankly, such efforts to organize and manage PKLs seem to have not been yet effective.

In our daily reality, a rationale is often built in and instilled into the people's minds who seem to accept blindly a pretextsaying that every public interest, in whatever form and strength, must be prioritized, championed, and put at the top before any individual or group interest. This kind of understanding is true since in Islam there is present a principle that says: ' $a$ maṣlahah al-'āmmah muqaddam 'alā al-mașlaḥah al- fardiyyah'which means 'a public interest precedes an individual one' [6]. However, some logical questionsthat should arise are: 1) is this the true meaning actually desired by ușüliyyun (the scholars of Islamic jurisprudence's fundament)? 2) Is it acceptable to evict PKLs (and other less fortunate groups of people alike) for the sake of preserving public interest and, if so, who actually has the right authority to do so? 3) How is the valid procedure to assess the public interest to be worthy of being prioritized? and 4) Do the motives, patterns, and objectives involved in the case of eviction of PKLs so far demonstrate good handling and are the evictions done with proper solution?

Fiqhmustad'afin as one trend of the Islamic contemporary jurisprudence does not only respond to legal issues, but also to all various life problems experienced by minorities and marginalized [7]. One of the discourses brought forward by fiqh is the ethicaltheological perspective based on the principle of justice and balance("adl wa tawāzun).

This study will observe cases of PKL evictions in Malang City, especially those having their business on Jalan Pahlawan TRIP, Klojen, as the weaks vis a visthe authoritarian and capital power that will be reviewed in the perspective of fiqhmustad'afin using maqāșid sharī'a (purposefulness of Islamic law) as the tool.

\section{MATERIALS AND METHOD}

Social reforms that are taught through transcendental revelations (i.e. the Qur'an and the Sunnah), must be based on the principles of justice and honesty, especially in socio-economic activities that involve the process of equitable distribution of wealth among people in a legitimate and fair manner. There should be no accumulation of wealth (capitalization) in whichmost assets and sourcesnecessitated for sustainability of people's life only circulate among the riches/the bourgeoisies [6], such is regulated in the Holy Quran Surah (QS) al-Hashr (59): 7 as in Ali [8]. Islam emphasizes the doctrine of equitable distribution of the living resources of people (i.e. socialism). The Quran and the Sunnah provide basic principles of Islamic teachings in the struggle to realize human solidarity and in fighting the system of capitalism and feudalism in a purpose to create human equality without any form of class differences [9, 10].

The verses of the QSal-Baqarah (2): 190-193; al-Nisā' [4]: 7-8 and 148; al-Anfāl (8):39; al-Tawbah (9): 36 and 103; al-Hajj (22):39; al-Hashr (59): 7-8; and al-Fajr (89): 6-14 forbid various forms of oppression, abuse, and exploitation of the poor and prohibit a lack of sense of social responsibility towards them (Ali, 1992:76-78, 185, 232, 423, 448, 468, 832, 1444-1445, 1645-1646) [8]. 
The QSal-Baqarah (2): 275-278; al-An'ām (6): 142; al-A'rāf (7): 31;al-Tawbah (9): 34; al-Hajj (22): 45; al-Shu'arā‘ (26): 151; al-Rūm (30):39; al-Żāriyāt [51]:19; al-Hashr (59): 7; al-Humazah (104): 1-4; and al-Mā'ūn (107): 1-3 oppose economic monopoly and capitalism and condemns as well as prohibits stockpiling and practices of accumulating wealth obtained through greed ethics and consumptive traditions (Ali, 1992:115-116, 336, 351-352, 447, 833$834,925,1018,1358,1444,1689,1704)[8]$.

In the QSal-Baqarah (2): 190; al-Nisā' (4): 75; al-A'rāf (7): 137; Yūnus (10): 14; al-Qașaṣ (28): 5; and al-Mā'ūn (107): 1-3, Islam defends the weak and oppressed and at the same time views the importance of the weak as leaders and heirs of the earth. Islam commands the believers to defend and fight for the oppressed weak and prohibits doing injustice against them (Ali, 1992:76, 207, 381-382, 483, 961-962, 1704) [8].

In the QSal-Baqarah (2): 188, 275, and 278279; al-Nisā' (4): 135; al-Māi‘dah (5): 8; al-A'rāf (7): 29; al-Tawbah (9): 34; Hūd (11): 84-85; and al-Rahmān (55): 8-9, Islam condemns unfair legal, social, economic, and politicalpractices and emphasizes the parameters of piety to the extent that it is able to uphold justice, egalitarianism, and equity (Ali, 1992:75-76, $115,116,228-229,248,351,447-448,533,1397-1398$ ) [8].

The Prophet Muhammad (peace be upon him, pbuh) often reminded us about our duties towards the weak. In one hadith (tradition) he said: “Weren't you helped and sustained because of the weak people among you?" [11]. He also said:"Truly Allah helps this ummah (Muslim community) owing to the weak people, namely because of their supplications, their prayers, and their sincerity" [12]. He said further: "Will I tell you who the people of the heaven are? They are every person who is weak and is considered weak by others, but if he/she swears in the name of God, surely God grants what he/she says. Will I tell you who are the people of the hell are? They are every person who is harsh, stingy, likes to pile up wealth, and arrogant" [11, 13].

The research was a mix-method type. Teddlie and Tashakkori [14] define mixed methods research (MMR) as a broad inquiry logic that guides the selection of specific methods and is informed through conceptual positions that are generally recognized by mixed methods practitioners.Apart from studying related literatures (i.e. the qualitative part of the research) discussing street trade in general as well as those discussing Islamic jurisprudence on mustad'afin, it also employed fieldwork (which is the quantitative part of the research) by interviewing a number of street vendors and officers of the government authorities concerned $[15,16]$. The interview used semi-structured questionnaires. The methods of data collection employed were: 1) Discussing the literature from the Quran, hadith, and those discussing human rights, legal pluralism, and street trade, 2) Reviewinglegal documents of acts including national and city's laws and regulations concerning street trade as well as observing national and city's data and newspaper reviews discussing this particular informal sector of economy, 3) Conducting semi-structured interviews to about one hundred PKLs especially those having their businesses along Jalan Pahlawan TRIP at Klojen, the city of Malang. They were taken as samples to observe their background, differences in trading, and vulnerability levels. The focus was to explorethe practices of street trade management such as the PKLs' personal characteristics, the characteristic of business and employment, and the presence of challenges and their responses, and 4) Conducting interviews with key informant comprisinggovernmental officers from the cityof Malang and the head of trader associations to determine the context for street trade and its formal and informal legislation. These fieldwork activities were conducted for 26 days from September $5^{\text {th }}$ to September $30^{\text {th }}, 2018$.

\section{RESULTS}

One of the biggest informal economic activities is street trade. Unfortunately, regulations concerning street trade is usually complexand very often applied unjustly. So, many PKLs face risk of unpredictable and devastating evictions [17]. PKLs in Malang carry out trading and non-formal business activities within a certain period of time by using public facilities that are determined by the Regional Government of Malang City as their place of business.One of routine incidental occasions which attract many PKLs to carry out their businesses is the Car Free Day (CFD) activities along the road of Jalan Pahlawan TRIP. More than 150 PKLs do their businesses thereon Sunday mornings from 05.00 a.m. to 11.00 a.m. usingsimple means such as carts, pickles, tables, chairs and mats (based on field observation, concluded on 27 September 2018).

The results of interviews to 110 PKLs and field observations gave the physical data of these PKLs as follows:

1. Based on the type of business, these PKLs do several types of businesses. The top five are selling food/beverages about $38.2 \%$, children toys $17,3 \%$, clothing 15,5\%, and transportation (including its equipments/apparatus and spare parts) $9.1 \%$ and simple electronic appliances 7,3\%.The rests sellgoods for hobbies including pets, any good of grocery store, home appliances, handicrafts, foodstuff, used goods, school equipment, and other michellaneous goods.

2. The means used are mostly non-permanent kiosks totalling of $23.6 \%$. 
3. The results of interviews showed that this profession is mostly carried out by those with low education (mostly graduates of elementary schools), small amount of capital $(1,000,000,00$ IDR or about 67 USD) [18], and they come from places outside Malang city (migrants) but are still in their productive age ( 25 to 54 years old).

4. Most PKLs, both migrants and locals, live in the city's slums so there is a difference between the two in their places to stay. Local PKLs must share the place with their family. Meanwhile most of migrant PKLs rent houses/rooms with their relatives or fellow PKLs. Residing in together or close to relatives and friends is a strategy to build social networks. It is important to start a strategy and maintain their business.

5. Many migrant PKLs leave their families in their original villages due to the city's high living cost. This strategy is taken so that they can maintain the lives of both theirs and their families at home. They usually return home at certain times to provide a living for their family (interviews with some PKLs and with Mr. Sulu Diono).

6. ThesePKLs have certain characteristics; they live frugally and utilize their leisure time for productive activities. They, especially those migrants who do not live with their family, cannot exercise the practice of wasteful and relaxed life. The findings of observation showed that they tended to use their spare time to produce anything sellable and minimize their daily expenses such as cigarettes and food purchased at retail. There were even those who traded goods or barter with fellow PKLs so that expenses can be reduced as much as possible. The method was taken to fulfill their costs such as renting a house or a room, meeting their family's needs at home, paying off debts, and even developing their business.

Some regulations in Indonesia related to one's right for having a decent job to fulfill their daily needs, including those specifically enacted to regulate street vendors, are:

1. The Indonesian Constitution of 1945, Article 27, paragraph 2 which states: "Each citizen shall be entitled to an occupation and an existence proper for a human being" [19]. The article 28A says:" Each person has the right to live and the right to defend his life and existence" [19].

2. The Indonesian Act No. 39 of 1999 on Human Rights Article 9 paragraph 1 says:"Every person has the right to live, to defend his/her life, and to increase his/her standard of living" [20].

3. The Indonesian Act No. 20 of 2008 on Micro, Mini, and Middle Scale of Business Activities Chapter V Article 13, paragraph 1 letter (a) which says:"The aspects of business opportunity as referred to in article 7 paragraph 1 letter $(f)$ is intended to determine the allocation of business place which includes providing such a place in markets, shopping areas, industrial centres, public farming locations, public mining locations, proper street vendors locations, as well as other locations" [21].

4. The Presidential Regulation No. 125 of 2012 on the Coordination of Arrangement and Empowerment of Street Vendors Article 3 paragraph 4 which states:" The displacement and abolition of street vendors' locations as referred to in paragraph 1 letter (c) shall be carried out to the locations which are not in accordance withtheir designated purposes" [22].

5. The Minister of Home Affairs Regulation No. 41 of 2012 on Guideline for the Arrangement and Empowerment of Street Vendors Article 36 paragraph 1 which says:"Street vendors who occupy locations not in accordance with their designation as referred to in article 12 paragraph 2 can be displaced or relocated to other placse/spaces designated for them" [23].

In doing their business, these PKLs are vis a vis with the city's government that is equipped with so many regulations. Restrictions on their business space by the government are usually in the form of licensing business locations, controlling, relocation, and eviction. Utilizing their authority and autonomy, the local government issueda regional regulation (Peraturan Daerah or PERDA) of Malang City no. 02 of 2012 on the Public Order and Environment [24] coupled with the Mayor of Malang's Decree no. 188.45/236/35.73.112/2016 on the Arrangement of Place or Location for Business Activities of Street Vendors [25]. These regulationsare intended as a guideline for structuring, fostering, empowering, monitoring, and controlling PKLs. The management of PKLs aims to improve their welfare and to maintain the public order and the environmental cleanliness. The main objective of the aforementioned regulations is to create employment for the people who fails to obtain their income from the formal sectors [26].

The ratification, issuance, and establishment of PERDA, Mayors' Decree or City's Circular Letter of Malang aims to simplify government steps in implementing a series of its development policies. The implementation of the government's policies is expected to overcome the problems that often arise due to PKLs or other informal sectors. Good arrangements are meant to fruit a good impact on the community, PKL communities, and the Malang City Government. The policies' realization is carried out with several steps that support, favor to, and do not harm any party concerned (interviewwith Mrs. Syska K. Damayanti).

The PERDA No. 2 of 2012 Chapter I article 1 verse 13 states that ' $P K L$ blocks are locations/areas destined for PKLs to sell; they are grouped based on the type of business and the trading time as determined.'Referring to this regulation, the PERDA 
states further that every PKL is prohibited from doing their business on roads, sidewalks, green lines and/or public facilities except on places permitted by the City's Mayor. Meanwhile, the Chapter III paragraph 21 of the same PERDA prohibits them from conducting business activities by establishing a semi-permanent/permanent business place and/or cause problems in terms of cleanliness, beauty, order, security and comfort [24].

The Article 3 Paragraph 1 of the said PERDA includes restrictions directed to PKLs, among others are: 1) conducting business activities in the city square and its surroundings, 2) conducting business activities on roads, sidewalks, lanes green and or other public facilities excluding certain areas that are permitted, 3) conducting business activities by establishing permanent or semi-permanent places, 4) conducting business activities that cause bad impactsrelated tothe city's cleanness, beauty, order, security, and comfort, 5) using a business place exceedingone permitted by the City's Mayor, 6) moving to other places and / or transferring permits without the knowledge and permission of the Mayor, and 7) abandoning and leaving the place empty without continuous activities for one month or more.

The arrangement of the place/location, time, type of street trading business are guided by the City's Regional Spatial Plan while taking into account the general, social, educational, economic, and aesthetic interests of the surrounding environment. The PERDANo. 2 of 2012 also regulates some restrictions for PKL.Its Chapter VII article 33 states that any person or body that violates the provisions of Article 4, Article 5, Article 21, and Article 22 is threatened with imprisonment for a maximum of 3 (three) months and/or a fine of at most Rp 10,000,000.00 (ten million rupiahs).Its implementation must go through stages that are in accordance with the procedures as regulated by PERDA.So, every violation must be handled through the Civil Servant Investigators which has the authority to: 1) examine those suspected of committing criminal acts in the field of public order, cleanliness and arrangement of street vendors, 2) request information and evidence from anyonerelated to incidents of criminal acts in the field of public order, cleanliness and arrangement of street vendors, 3) conduct an examination of documents related to a criminal offense of public order, 4) conduct inspections in certain places suspected of containing evidence and other documents as well as to confiscate and seal materials and goods resulting from violations that can be used as evidence in criminal cases in terms of public order and arrangement of street vendors, and 5) request assistance from experts in carrying out investigation tasks of criminal offenses on public order, cleanliness, and arrangement of street vendors [24].

In realizing public order, security and convenience, the Civil Service Police Unit (Satuan
Polisi Pamong Praja or Satpol PP, Ind.) and the Department of Transportation are authorized to enforce the PERDA No. 02 Year 2012 and the Mayor's Decree No.188.45/236 /35.73.112/2016.So, being equipped with those regulations, in August 2018 an ordering action of PKLs along Jalan Pahlawan TRIPthat had been used to do their businessevery Sundayfor the last four years was done $[27,28]$. This location is considered as aprohibitedplace for street vendors activities.The Mayor's Decree No.: $188.45 / 183 / 35.73 .112 / 2015$ issued a year earlier concerning the Arragement of the Location of Street Vendors' Business Activities, explained about several locations that were prohibited from selling street vendors. Locations that were prohibited for street vendors are divided into 5 (five) sub-districts namely Blimbing, Klojen, Lowokwaru, Sukun, and Kedungkandang with 23, 71, 15, 7, and 9 places respectively. Those locations are forbidden with a consideration that they are the main road, heavy traffic lane, conservation zone, military area, public settlement, educational area, and green open spaces [29].

Actually, those PKLs in Jalan Pahlawan TRIP did their business based on an unwritten permit given by the previous mayor who had themotto ofpeduli wong cilik (caring for marginalized people). The replacement of the Mayor of Malang city in 2018 brought with him new policies relating to PKLs in the city. The new-elect mayor introduced and enacted policy changes regarding PKLs and those operating in Jalan Pahlawan TRIP were of no exception.In hisview, the existence of PKLs along Jalan Pahlawan TRIP was considered disturbingpublic interest and the community's comfort. Therefore, an ordering measure was then taken [26].

The eviction steps carried out did not jump directly to the eviction operation itselfbut there were preliminary steps including counseling and guidance for PKLs to eliminate or reduce all forms of threats and disturbances of order due to their business location that did not consider the convenience of other road uses. One way of fostering peace and public order is the dissemination of legal products, especially PERDA, decrees of regional heads, and other legal products. This cannot be done immediately, so it is necessary to do it in proper stages so that the community can understand and abideany regulation of the national, provincial, and local governments. Counseling and coaching become important activities in curbing PKLs in a persuasive manner. Such are done to foster awareness among them that they have violated applicable regulations which are prohibited byconducting businesses on prohibited locations including Jalan Pahlawan TRIP [5].

Basically, the PKL eviction by the Satpol PP of Malang were conductedin two approaches, preventive and repressive ones. The preventive approach was done through counseling, guiding, and 
educating individuals and community groups that are thought to be the source of the emergence of public order's disturbances. Meanwhile, the repressive measure was conducted through raids or orderenforcement operations. Any policy based on a win-win solution in the government's version is expected to be able to realize a beautiful, clean, and orderly city without ignoring the aspect of empowering street vendors. The Satpol PP of Malang City functions themselves as the enforcer of PERDA's regulations to control and arrange the street vendors since it is seen as the only way out to solve the city's problems of traffic congestion, beauty, and cleanliness [30].

\section{DISCUSSION}

Wasiti [31] states that the economic conception of informal sector only emerged in 1969 and continued to be developed when the International Labor Organization (ILO) initiated and developed the World Employment Program (WEP) program. The program aims to find the right economic development strategy that is capable of overcoming employment problems in developing countries which in fact, despite their accelerating economic development, their unemployment rate is still high. Furthermore, Wasiti [31] also explains that the informal sectorsactually have competitive economic contributions: they are labor intensive, they utilize local inputs and technology, and they operate based on their own ideas, capital, management, and risks. Furthermore, the emergence of the informal sectors is not only due to the lack of jobs but also to accommodate jobs that are wasted from the formal sector alone. In fact, the informal sectorsare able to subsidize the formal ones because as an economic pillar, the latter tend to be less efficient, while the formerare fairly efficient for being better able to provide cheaper life needs [31].

Informal sector actors are often assumed to be a form of underdevelopment and low human resources. In terms of economy, they are considered illegal so that they often become the target of evictions. Sociologically, it is understandable thatmany products of regulations relating to urban planning are often merely a space cooperation between the city authorities and capital owners (entrepreneurs). This is paradox to what the reality says. The Indonesian Central Bureau of Statistic noted, through its Director, that in August 2018 their data recorded unemployment at 5.34 percent or 7 million people. Unemployment in urban areas was higher than in rural ones. The number of Indonesian workforce reached 131.01 million people. The informal sectors still became the primadona. In August 2018, $56.84 \%$ of the population worked in informal activities [32].

The employment sector tends to be vulnerable to the interests of certain parties, especially with high unemployment in developing countries [33, 34]. The existence of PKLs is quite helpful in overcoming the problem of unemployment in Indonesia, so is in Malang City, as well as becoming one of the sources of income for the City's locally generated revenue.PKLs grow rapidly since consumers can find them easier compared to settled similar businesses. Many public or even family occasions and crowds can turn into an impromptu businessfield and place for PKLs in seekinghalāl (Islamically allowable) income. PKLs have an important role to improve the community's economy, especially the low incomers.However, this informal sector contributes pretty significantly to urban development since through its chain of activities it can also increase city residents' income in various forms ranging from home rentals, groceries, parking lots, etc.Unfortunately, the rapid growth of this sector is not handled effectivelynor planned properly.

The economic informal sectors, including PKL,are in fact able to support the State's inability to provide employment for its citizens. These sectors are capable of absorbing the working-aged-peoplewith relatively minimal expertise and educational qualificationand overcoming unemployment in Indonesia which increases every year. In Indonesia, the informal sector accounts for at least two-thirds of the national economy [35]. This structure is a strategic part of the system, but at the same time it is a complicated problem.

Unfortunately, the facts often say otherwise. The eviction of PKLs in Malang causes different impactsto those targeted. Actually, PKLsat the location of Pahlawan Trip are very much welcomed sincethe said area is destined to be the CFD location that has been a common activity in any Indonesian city and town. Such eviction causes connoisseurs of CFD no longer feel the excitement of enjoying the weekend with its various cheap culinary and other merchandises whereas PKLs lose their source of livelihood.

In Indonesia, being not pretty wanted by the city policy makers, PKLs, as a proletarian economic group, often become victims of regulations. Various phenomena of forced and arbitrary eviction of PKLs are only a small example of welfare and justice that the government often overrides in making policies. This unfair and unbalanced structure of relations is the result of mutual cooperation between the government and capital institutions. In doing so, the marginal community's rights are often neglected and sacrificed. In our analysis, this impartiality is caused by development that is not followed by awareness of providing opportunities and situations that support the development and participation of informal sectors [34]. Therefore, justice commitment as the heart of social welfare and political philosophy of the founding of this republic needs to be reviewed, monitored, and overseen massively by all Indonesian people as the true stakeholders of this country. The state must be able to uphold and promote justice and prosperity for all 
people, especially for the proletariat and the marginalized.

In the midst of efforts to force evictions and relocation, the PKLs staged a resistance, both hidden and open, to maintain their business. A number of studies have seen various forms of resistancesby PKLs in facing evictions: through a "noncompliance" strategy taking advantage of the weaknesses of the state, developing individual or collective strategies to deal with the threat of eviction [37] or manipulating the political system for their interests [38]. However, the previous researches generally agree that evictions are merely short-term solutions and will not be effective in eliminating informal economic activities in urban areas. Furthermore, there are often cases where the policy of limitation and prohibition is actually a means for other parties to exploit PKLs. In the PKL mapping activities in Malang City, for example, it is common to find that those PKLs pay a sum of money to some "naughty" officers or "thugs" in return for hopes that their business, which is done on prohibited locations, will not be evicted. For PKLs, the money paid is probably not as long as it is guaranteed that their business will not be evicted. Some PKL organizations also play a similar role as intermediaries or guarantors of PKLs against the government. This phenomenon shows that PKLs are indeed vulnerable to forms of exploitation from other parties.

PKLs are a part of mustad'afin. According to Ridwan [1], mustad'afin means a group of marginal groups or weak people i.e. the low level class of society who are often persecuted and taken away off their rights.People ofmustad'afinarea product of structural, political, and economic tendencies. They will continue to grow and increase, especially after the eviction of PKLs and other local economic potentials. Mustad'afin includeindividuals and or social groups who : 1)are in the position of 'minority' (qalìl) both quantitatively and qualitatively, 2) suffer from vulnerability to structured oppression either by political, economic, and social policies (istiḍ'af), and 3) have not been free from fear (khawf)so they do not have the courage to fight against any oppression.

In his book, Hasan Hanafi [39] personified the Prophets Abraham (pbuh) as a mirror of the mind revolution and monotheism subduing the traditions of blindness and idols, Moses (pbuh) reflected the liberation revolution against authoritarianism, Jesus (pbuh) revolutionized the spirit of the dominance of materialism, then Muhammad (pbuh) was the hero of the proletariat, slave servants, and oppressed communities who were confronted by the elite bourgeoisie of Quraysh [40, 41]. Jalaluddin Rahmat [42] described Islam as a religion that favored the weak, oppressed, and underdeveloped or the religion of mustad'afin. In line with him, Asghar Ali Engineer [43] elaborated that the aim and ideals of Islam is the creation of universal brotherhood, equality, and social justice. The themes of populism and the ideals of Islamic social order enforcing an elastic, egalitarian, and just social order become the theological foundations of fiqhmustad'afin.

Why should it be fiqhmustad'afin? This is because fiqhmustad'afin has a vision to defend as well as advocate those who are weak and persecuted and not the opposite: defending power by protecting it through religious symbols. Fiqhmustad'afin belongs to those who are weak, weakened, or oppressed as well as placing those people who do wrong and unfair as enemies that must be fought. In other words fiqhmustad'afin was born as one which is pro to weak people (i.e. an often oppressed group of people), not a pro-ruler one. This fiqh is endeavored to always move and be moved by and for the sake of majority people. It becomes a humanisticfiqh that opposes the structural and authoritarian one. The actualization of fiqh mustad'afin can be started by expanding the categories ofmustad'afin which should include new victim groups, which are not yet known in the common concepts. Furthermore,it must be rearranged how systematically redistribution process can raise their status of helplessness.

Furthermore, Jursyi [44] states that fiqhmustad'afinis oriented towards liberation as initiated by progressive liberative-transformative Islam. In the context of fiqhmustad'afin, liberation means deconstructing and reconstructing a social order that is full of deviations and injustices. Such is in accordance with the treatise carried by all the Prophets and Apostleswhich is the liberation of man from the bondage of tyranny to the pure submission to his/her Creator alone. In other words, borrowing Roscoe Pound's legal-philosophical terms: 'fiqhmustaḍ'afindoes not only function to maintain the stability of social life (i.e. the fiqh as a tool of social control) but also as a means of social engineering and social revolution' [45].

Every citizen, including PKLs, has the right to refuse eviction if the process does not pay attention to the human dignity and fate and neglects sustainability of human life and social ethics. The state, according to Syafi'i SJ [6], which is guided by the supreme divine precepts, ideally demonstrates an attitude of inclination to the people who are loved by God (i.e. the proletariat,the poor, and the marginalized).Furthermore, as Muslims, who are the majority population in Indonesia, they are also required to re-actualize the conception of fiqh mustad'afin(proletarian jurisprudence) as a manifestation of the actualization of universal benefit which itself is the substance of Islamic teachings. One form of the said re-actualization is a resistance movement against the rationale and reason under the jargons of "development" and "public interest" over the eviction onthe people's livelihood sources which basically is nothing more than just 
actions of "image branding" for the interests of a bunch of conglomerate (bourgeois) persons.

A rationale of the nation's development that has already become a protracted doctrine in people's minds, thoughts and beliefs is that every "public interest", - in whatever form and strength,- must be championed and prioritized over any "certain individuals and groups' interest". In the Islamic teaching, one of its legal theories asserts that "al-mașlahah al-'ammah muqaddam 'alā al-mașlahah al-fardiyyah" (a public interest precedes an individual one) [6]. However, the application of the said doctrine and theory must be read and observed critically, such as whether it is substantively true that it is indeed for the sake ofpublic interest and not for certain individuals or groups quibbling behind the terms of public interest. Can the eviction of the proletarian group,- in this case PKLswho worked for fulfilling their daily needs,- for the sake of attaining public interest and order without proper relocation and solution and was not done with proper and polite manner, be considered as a form of justice? So far it is commonly known that in Indonesia, any eviction is often taken for granted and legally operatedwithout proper negotiation and free from any intervention. In the context of PKLeviction in Malang, an understanding of oppression is more related to authority and structural problems.

Viewing from the aspect of public benefit which might be jeopardized by the usage of public facilities by PKLs, the Malang's government has indeed issued regulations and policiesconcerning the public interest, but, unfortunately, those rules have become blunt when dealing with economic capital actors. It is sad to see that structural casualties of evictions so far are still inherent toPKLs and other helpless groups alike whereas big companies, malls, superstores, and many other businesses owned by conglomerates that also violate the city's spatial plan and environmental impact analysis remain untouched. Indeed, the contemporary economic system has given rise to many dimensions of poverty and oppression.

What is then interesting is the substance of mașlahạt (benefits) and madarāt/mafsadāt (harms/disadvantages) from the relinquishment of public facilities. Referring to the Islamic concept, the main purpose of law enactment through the process of ijtihād (intellectual exercise) is to realize the benefits/welfare for mankind, - individuals and groups, rich and poor, male and female, etc., - as well as resisting any harm for them (jalbu al-mașālih wa dar' $u$ al-mafāsid). This is in line with a legal maxim in fiqh that states: tașarruf al-imām 'alā al-ra'iyyah manūtun bi al-mașlahah (a policy made by a leader towards his people is based on attaining benefit for them). In the perspective and substance of fiqh mustad'afin, the benefit meant here is one which emphasizes the spirit of embodying goodness and balance.
Imam al-Ghazali classified mașlahahinto three: 1) general mașlahah which must be upheld together ( $m \bar{a}$ yata'allaq bi mașlahah 'āmmah fịhaqqi käffah), 2) mașlahah relating to the majority of humans ( $m \bar{a}$ yata'allaq bi mașlaḥah al aghläb), and 3) mașlaḥah that occurs in individuals and occurs in certain events and circumstances (mā yata'allaq bi mașlahah shakhshin mu'ayyamin fiwāqi'atin nāziratin). Regarding this classification, the Islamic juristsgenerally only comment on the forms of mașlahahwhenever there presentcontradictions at the time they are related to the selection of best opinions (tarjīh). In this regard, they prioritize the general mașlahah than individual one. However, to the authors' opinion, the legal maxim that states "al-mașlahah al-'ammah muqaddam 'alā almașlahah al-fardiyyah" (a public interest precedes an individual one) in some contexts need to be explained and applied wisely to obtain the best and acceptable solution for all. Otherwise, this maxim is prone to be used as a legitimacy and justification by the government conducting any operation for restoring order including eviction of street vendors in Malang [46, 47].

The thing that has to be observed wisely is that, on the pretext of public interest, any individual or groups' interest may be ignored even thoughIslam has safeguarded some basic personal interests such as fulfilling one's and family's livelihood.Islam, through its maqāsid sharī'ahas taught a concept of hifz aldin,hifz al-nafs,hifz al-nasl,hifz al- 'aql, hifz al-māl, and hifz al- ird (preserving one's religion, soul, offspring, intelligence, wealth, and dignity respectively), which are termed as al-kulliyyah al-sitt (the six basic elements) [48]. Many cases of evictions under the guise of implementing development for the public interest neglected that concept. Equipping themselves with the pretext of 'prioritizing public interest'the government (who often collaborate with the economic elites) often used it as the most powerful tool to seize the rights of the marginalized people. In the name of preserving order, cleanliness, and public interest or preventing traffic congestion, the government often took the PKLs' stalls forcibly without thinking of the consequences for them on how to support their families fulfilling their daily needs.

According to the Mayor's decree, Jalan Pahlawan TRIP is listed in the red zone areas which is prohibited for street vendors although, but they have unwritten permit and mandates from the previous Mayor and paid retribution to the city and such condition had been running for years. Based on the pretext of preserving public interest, evictionswithout a proper solution was carried out. There emerged at least two questions regarding these evictions: whether in this context relating to PKLs personal interests are placed above the public ones, or vice versa. This simplistic dichotomy is certainly not adequate. Referring to the two aforementioned questions,in our opinion, if an 
individual interest does concern and relates closely with one's human rights, then the public interest must be placed after it. Even morally, the government or the State must respect and uphold the basic individual interests.

With the aforementioned principle, the implementation of the eviction of street vendors in Jalan Pahlawan TRIP or of any other people's livelihood occurring at the moment must be put in proportion. So, if the eviction was done by the government for preserving the public interest and it can be verified that there was no other alternative, then the public interest takes precedence but such decision must be followed by relocating them to the same strategic places. This principle must be applied fairly whether addressing business places of the marginal minority groups or the bourgeois elite ones.

The eviction of street vendors in the name of public interests must be based on agreement and negotiation with the principle of willingness of both parties and must bring along with it strategic relocation solutions for the aggrieved parties so as not to decrease their economic standards. The eviction must be accompanied by guaranteed access to proportional and humane economic values. So, prioritizing the public interest over the individual one can be justified as long as it can accommodate the element of 'goodness, justice, and balance'.

There are someprinciples that must be considered in the case of eviction of PKLs. The principles of need and of benefit guide the government notto impose its policies in the name of preserving public interest by underestimatingany madarāt (harms) to them such as impoverishment and extermination of their livelihood sources. The principle of agreement and understanding necessitates a negotiation process between two parties especially regarding the future solutions. With this principle, the eviction under any pretext cannot be justified when ignoring necessary and appropriate solutions. Evictions can only be justified based onthe presence of an agreement between the two parties by considering the universal human rights, the government's alignment to the minority community (i.e. PKLs), and a guarantee of life standard's quality.

Islam teaches its followers to work hard to attain good life in this world and to foster prosperity for all as their mission as vicegerents of Allah on this earth. Therefore, any conduct that may threaten one's life and livelihood is against the Islamic teaching. Such situation can be seen from the impacts of improper evictions. The victims of such evictionsdo not only lose their place and source of livelihood but also the opportunity to live properly as human beings. So, any eviction resulting inextermination of one's livelihood sources is a crime against humanity that must be stopped. This is in line with the message of the Prophet Muhammad (pbuh) who said: "If you are killed (while defending your rights) then you are martyred, and if he/she (i.e. the wrongdoer)is killed, then he/she goes to hell" [11, 13]. Fighting a tyranny (the crime of humanity) itself is a religious obligation, including defending the weak (dúafá) and being weakened (mustad'afin), because this is in accordance with Allah's command which states: fala takhshauhum wakhshauni (Yet fear them not, but fear Me) (QS al-Maidah (5): 3 as in Ali, 1992: 244-245) [8].

However, on the other hand, if evictions are done by fulfilling the aforementioned prerequisites, the pretext which states that 'a general benefit is prioritized over a specificone' can be implemented, so such eviction of PKLs can be carried out by the just government or public leaders. And, we, as the common people, must obey the just leader's policy and regulationsince doing so is obligatory. Allah says:"O ye who believe! Obey Allah and obey the Messenger and ulil amri (those charged with authority) among you" (QS al-Nisā (4): 59as in Ali, 1992: 203) [8].

Evictions should also consider the principle of development that has human rights perspective which pivots on the values of humanity, environmental, equitable distribution, and human resource development. A development must be understood as a comprehensive economic, social, cultural, and political process. Its objective is a thriving progress on the wellbeing of every resident and individual based on free and active participation. The substance of this development isas mandated by the Article 28D paragraph (2) of the Indonesian Constitution of 1945 which says: "Every person is entitled to an occupation as well as to get income and a fair and proper treatment in labor relations" [19], $2^{\text {nd }}$ amendment of 18 August 2000). The provision shows constitutionality of one's rights onoccupation and work as part of human rights. Therefore, the state must facilitate the openness and availability of employment as well as provide dignified life space in the job world.

Fiqh mustad'afinbased on theQur'anic universal values in the form of a humanitarian project aims to demolish the dividing wall between the weak people and the powerful ones. In the case of PKL eviction, viewed from the justice perspective, PKLs areweak people becoming victims of policies. Therefore, upholding justice values as the main mission of fiqh mustad'afin must continue to be pursued. Its reactualization is expected to foster the city government'sstanding positionto the informal sectors' activities, including PKLs, thereby erasing the impression that they areneglected and marginalized. The City Government's support for the provision of facilities to foster development and improving competitiveness of vendors is, therefore, very much needed. 
As already known, the liberal capitalism economic system does not have a positive impact on efforts to improve the welfare of the weak/marginalized; it actually even raises a fairly clear distance and gap between the poor and rich communities. In such a condition, the religion (i.e. Islam) and its legal product (i.e. fiqh) must come forward as anti-establishment drivers and a very effective media for revolutionary movements to realize a just society and defend the marginalized.The proletarian jurisprudence should use the cases of evictions, including those of PKLs, as its best momentum to reactualizeits presence and function. Again, this is because in such evictions, no proper winwin solution is ever offered and taken, the weak always become helpless victims, and eventually the government only presents itself as a scourge for those weak people by confronting them with policies that do not favor them. This can be attained when proper understanding of fiqh mustad'afinis disseminated to all level of community, especially the government as the authority holder of the public affairs. Having done so, anygovernment at all levels will take heavy its functions, one of which is to promote public welfare and to increaseits people's level of economy through efforts of empowering street vendors such as by providing guarantees, protection, guidance, and regulation in a purpose of having efficient, effective, and law-abiding business.

\section{CONCLUSION}

From the previous discussion, we can conclude the following two things: first, various phenomena of forced and arbitrary eviction of street vendors are only a small example of neglected welfare and justice whenever the governmentsissuetheir policies. This unfair and unbalanced structure of relations results fromunhealthy mutual cooperation between the governments and capital institutions that neglect marginal community's rights. With this condition, the justice commitment as the heart of social welfare and political philosophy of the founding of the nation of Indonesia which is patented as the fifth precept of the national philosophy, "Social justice for all Indonesian people", seems to be uprooted. Second, re-actualizing fiqh mustad'afinshould always be present in the situation of living under the control of hegemonic, oppressive, and authoritarian power.Such reactualization of this proletarian jurisprudence at least carries four important missions: 1) fomenting the spirit of resistance to whatever is considered oppressive, 2) freeingthe society from any form of confinement, 3 ) giving a paradigmatic foundation for various resistance movements, and 4) being partial to minority, weak, oppressed, and marginalized communities resulted from physical and non-physical oppression by advocating and organizing them.

\section{ACKNOWLEDGMENT}

The study was self-funded, however, we would like to express our sincere gratitude to librarians at the IAIN Tulungagung - East Java for their tireless and time consuming assistance in providing materials (books, journals, magazines, etc.) to us during our research, street vendors of Jalan Pahlawan TRIP, Klojen, Malang, and officers of the City of Malang's government offices who took part as informants for this study.

\section{REFERENCES}

1. Ridwan, N. K. (2004). Agama Borjuis: Kritik Atas Nalar Islam Murni[The Bourgeuis Religion: Criticism on Pure Islamic Reasoning].Jogjakarta: Ar-Ruzz.

2. Chandra AP, Tri. (2002). "Reforma Agraria: Perbincangan yang Belum Selesai di Tengah Pergulatan Islam Liberal dengan Islam PostTradisional" [The Agrarian Reform: Unfinished Talk in the Middle of Liberal Islamic Struggle with Post-Traditional Islam], Tashwirul Afkar: Deformalisasi Syariat, 12. Jakarta: LAKPESDAM NU.

3. Government of Malang City (GMC). (2016). Keputusan Walikota Malang No.: 41 Tahun 2016 tentang Kedudukan, Susunan Organisasi, Tugas, dan Fungsi serta Tata Kerja Dinas Perdagangan [Mayor's Decree No.:41 of 2016 on the Position, Organizational Structure, Duties, and Functions of Job Arrangement of the Office of Trading].

4. www.id.wikipedia.org/wiki/Pedagang_kaki_lima,( accessed on 3 March 2019).

5. Interview with Mr. Didik Ary, The Section Head of PKL Affairs of Malang City (27 September 2018).

6. Syafi'i SJ, A. (2017). Fiqh Proletar: Rekonstruksi Nalar Kepentingan Umum dalam Kasus Pembebasan Tanah untuk Pembangunan Menuju ke Arah Transformasi Sosial yang ProgresifHumanis [The Proletarian Fiqh: Reconstructing the Notion of Public Interest in the Cases of Land Liberation for Development towards a Progressive-Humanistic Social Transformation]. FIKROTUNA, 3(1): 1-44.

7. al-Alwani, T. J. (2010). Towards a Fiqh for Minorities. $2^{\text {nd }}$ ed.London: IIIT. ISBN-10: 1565643526, ISBN-13: 978-1565643529.

8. Ali, Ab. Y. (1992). The Meaning of the Holy Qur'an. Maryland, USA : Amana Corporation, ISBN-10: 0915957116, ISBN-13: 9780915957118.

9. Abdulgani, Roeslan. (1965).Api Islam dalam Kobaran Api Revolusi Indonesia [The Fire of Islam in the Flames of Indonesian Revolution].Jakarta: B.P. Prapantja.

10. Supriyadi, E. (2003). Sosialisme Islam: Pemikiran Ali Shari'ati [Islamic Socialism: The Thoughts of Ali Shari'ati] (Yogyakarta: Pustaka Pelajar. 
11. al-Bukhari, M. (1998). ȘaḥiḥalBukhārì [Compilation of the Prophet Traditions by al-Bukhari], Riyadh, KSA: Baitul Afkar AlDauliyah.

12. al-Nasa'i, I. (1978). Sunan al-Nasā'i [Compilation of the Prophet Traditions by al-Nasa'i], Beirut: Dar al-Fikr.

13. Muslim, I. 2001. SahịhMuslīm [Compilation of the Prophet Traditions by Muslim], Riyadh, KSA: Maktabatur Rusyd.

14. Teddlie, C., \& Tashakkori, A. (2010). Overview of Contemporary Issues in Mixed Methods Research, in Sage Handbook of Mixed Methods in Social \& Behavioral Research, eds. Tashakkori, A. and Teddlie, C. $2^{\text {nd }}$ ed. Los Angelos: SAGE Publication.

15. Kothari, C. R. (2004). Research Methodology: Methods and Techniques, $2^{\text {nd }}$ ed. New Delhi: New Age International.

16. Creswell, J. W. (1998). Qualitative Inquiry and Research Design: Choosing among Five Traditions. Thousand Oaks, CA: SAGE.

17. Brown, A. (2016). Making Space for the Poor: Law, Rights, Regulation \&Street-trade in the $21^{\text {st }}$ Century. [data collection]. UK Data Service. SN: 851365.

18. www.exchange-rates.org/Rate/USD/IDR/9-302018. (accessed on 20 Feb 2019).

19. Government of Indonesia.(1945). Undang-undang Dasar Tahun 1945. [The Indonesian Constitution of 1945], with its $1^{\text {st }}$ amendment (19 October 1999), $2^{\text {nd }}$ amendment (18 August 2000), $3^{\text {rd }}$ amendment (19 November 2001), and $4^{\text {th }}$ amendment (10 August 2002). Available on: http://www.unesco.org/education/edurights/media/ docs/b1ba8608010ce0c48966911957392ea8cda40 5d8.pdf. Accessed on Feb 4, 2019.

20. Government of Indonesia. (1999). Undang-undang No. 39 Tahun 1999 tentang Hak Asasi Manusia [Act No. 39 of 1999 on Human Rights]. Available on:

https://www.komnasham.go.id/files/1475231474uu-nomor-39-tahun-1999-tentang-\$H9FVDS.pdf Accessed on Feb 4, 2019.

21. Government of Indonesia. (2008). Undang-undang No. 20 Tahun 2008 tentang Usaha Mikro, Kecil, dan Menengah Indonesian [Act No. 20 of 2008 on Micro, Mini, and Middle Scale of Business]. Available on: https://www.bi.go.id/id/tentangbi/uu-

bi/Documents/UU20Tahun2008UMKM.pdf.Acces sed on Feb 5, 2019.

22. Government of Indonesia. (2012). Peraturan Presiden No. 125 Tahun 2012 tentang Koordinasi Penataan dan Pemberdayaan PKL [The Presidential Regulation No. 125 of 212 on the Coordination of Arrangement and Empowerment of Street Vendors], available on: http://ditjenpp.kemenkumham.go.id/arsip/ln/2012/ ps125-2012.pdf. Accessed on Feb 4, 2019.
23. Government of Indonesia. (2012). Peraturan Menteri Dalam Negeri No. 41 Tahun 2012 tentang Pedoman Penataan dan Pemberdayaan PKL [The Minister of Home Affairs' Regulation No. 41 of 212 on Guideline for the Arrangement and Empowerment of Street Vendors], available on: http://ditjenpp.kemenkumham.go.id/arsip/bn/2012/ bn607-2012.pdf. Accessed on Feb 4, 2019.

24. GMC. (2012). Peraturan Daerah No. 2 Tahun 2012 tentang Ketertiban Umum dan Lingkungan [Regional Regulation No. 2 of 2012 on The Public Order and Environment]. Available on: https://hukum.malangkota.go.id/download/perda/p erda2012/SALINAN\%20PERDA\%20NOMOR\%20 2\%20TAHUN\%202012\%20TENTANG\%2OKETE RTIBAN\%20UMUM\%20DAN\%2OLINGKUNGAN .pdf(accessed on 13 Jan 2019).

25. GMC. (2016). Keputusan Walikota Malang No.: 188.45/236/35.73.112/2016tentang Penetapan Tempat atau Lokasi Kegiatan Usaha Pedagang Kaki Lima (PKL) [Mayor's Decree No.: 188.45/236/35.73.112/2016 on the Arrangement of the Location of Street Vendors' Business Activities].

26. Interview with Mr. Parlindungan Hutasoit, The Head of the Section for Ordering the Small and Middle Business of Malang City (30 September 2018).

27. Bagas and Mega, M. (ed.).(2018). "PKL Pahlawan TRIP Sayangkan Penggusuran Tanpa Sosialisasi" [Street Vendors of Pahlawan TRIP Regret Eviction Without Socialization], Kabarpas.com, Aug 19, Available on:http://www.kabarpas.com/2018/08/19/pklpahlawan-trip-sayangkan-penggusuran-tanpasosialisasi/(accessed on 2 Jan 2019).

28. Irawan and Bua (ed.), (2018). "Tidak Boleh Jualan di Jalan Pahlawan Trip, PKL CFD Wadul ke DPRD" [Prohibited to Do Business on Jalan Pahlawan TRIP, CFD Street Vendors Complain to the Local Parliament], Malangpostonline.com, Aug 6, Available on: https://www.malangpostonline.com/read/3678/tida k-boleh-jualan-di-jalan-pahlawan-trip-pkl-cfdwadul-ke-dprd.(accessed on 2 Jan 2019).

29. GMC. (2015). Keputusan Walikota Malang No.: 188.45/183/35.73.112/2015 tentang Penetapan Tempat atau Lokasi Kegiatan Usaha Pedagang Kaki Lima (PKL) [Mayor's Decree No.:188.45/183/35.73.112/2015on the Arrangement of the Location of Street Vendors' Business Activities].

30. Interview with Mrs. Syska K. Damayanti, a staff of the Section for Ordering the Small and Middle Business of Malang City (30 September 2018).

31. Wasiti. (2009). Eksistensi Sektor Informal dan Upaya Pembinaannya The Existence of Informal Sectors and Their Coaching, INFORMASI, 35(2): 93-101. 
32. Sukmana, M. I., Torkura, K. A., Cheng, F., Meinel, C., \& Graupner, H. (2018, January). Unified logging system for monitoring multiple cloud storage providers in cloud storage broker. In 2018 International Conference on Information Networking (ICOIN) (pp. 44-49). IEEE.

33. Lewis-Beck, M. S., \& Paldam, M. (2000). Economic voting: an introduction. Electoral Studies, 19(2/3): 113-121.

34. Mueller, D. C. (2003). Public Choice III. Cambridge: Cambridge University Press.

35. Gunawan,B. T. (2018). Pengaruh Pemilihan Kepala Daerah terhadap Pasar Tenaga Kerja: Analisis Sektor Formal dan Informal Level Kabupaten/Kota di Pulau Jawa [The Impacts of Heads of Local Government Election to the Labor Market: an Analysis of Formal and Informal Sectors at the Regency/City Level in Java], Kajian Ekonomi Keuangan, 2(2): 149-161.

36. Rachbini, D. J., \& Hamid, A. (1994). Ekonomi Informal Perkotaan[Urban Informal Economy], Jakarta LP3ES.

37. McGee, T. G. (1973). Hawkers in Hong Kong: a Study of Planning and Policy in a Third World City. Hong Kong: Center of Asian Studies University of Hong Kong.

38. Cross, J. C. (1998). "Co-optation, Competition, and Resistance:State and Street Vendors in Mexico City. " Latin American Perspectives, 25(2): 41-61. Available on: http://www.jstor.org/stable/2634061(accessed on 3 Feb 2019).

39. Hasan, H. (2001). Islam Wahyu Sekuler [Islam, the Secular Revelation], trans. Husein, M. Zaki\& Khoiron, M. Nur. Jakarta: Instad.

40. Mustafied, M. (2000). Merancang Ideologi Gerakan Islam Progresif Transformatif:
Mempertimbangkan Islam Kiri Hassan Hanafi [Designing the Ideology of the Transformative Progressive Islamic Movement: Considering Hassan Hanafi's Left Islam]. In Sosialisme Religius, Suatu Jalan Keempat [Religious Socialism: a Fourth Way].ed.Dahlan, Muhiddin M. Yogyakarta: Kreasi Wacana.

41. Riyadi, H. (2005). Tafsir Emansipatoris: Arah Baru Studi Tafsir al-Qur"an [Emancipatoric Interpretation: New Directions for Interpretation of the Qur'an]. Bandung: Pustaka Setia.

42. Rakhmat, J. (1991). Islam Alternatif [The Alternative Islam]. Bandung: Mizan.

43. Ashghar A. E. (1990). Islam and Liberation Theology. New Delhi: Sterling Publishers Private Limited.

44. Jursyi, S. (2000). Al-Islämiyyūn alTaqaddumiyyūn [Earthing the Progressive Islam], trans. Shah, M. Aunul Abied. Jakarta: Paramadina.

45. Pound, R. (1979). "In My Philosophy of Law", in Ervin H. Pollack (ed.), Jurisprudence: Principles and Application, Ohio-USA: Ohio State University Press.

46. al-Ghazali, I. (1971). Sharaḥ al-Ghalīl fi Bayāni al-Shabahi wa al-Mukhayyal wa Masāil al-Ta'līl [The Noble Explanation on the Spook and Imaginative Statements and Issues of Reasoning]. Baghdad: Mathba'ah al-Irshad.

47. Husayn, H. H. (1971). Nazariyyah al-Mașlahah fi al-Fiqh al-Islām[Analyzing the Benefits in Islamic Jurisprudence], Beirut: Dar al-Nahdlah al'Arabiyah.

48. Ibn al-Subki, Taj al-Din 'Abd al-Wahhab. (2005). Hashiyah al- 'Allamah al-Bannāni 'alā Matn Jam'i al-Jawāmi, Chap. 2.Beirut: Dar al-Kutub al'Ilmiyyah. 